\title{
Caesarian section rates in private and public hospitals in Eritrea in 2007
}

\author{
'Bereket Sebhatu MD and ${ }^{2}$ Assefash Zehaie MD
}

Institutional affiliation:

'Orotta National Referral Maternity Hospital Asmara, Eritrea, ${ }^{2}$ Orotta National Referral Pediatric Hospital, Asmara, Eritrea

Corresponding author

Dr. Bereket Sebhatu

Orotta National Referral Maternity Hospital, Asmara, Eritrea; E-mail: warkamoy@yahoo.co.uk

Background: Caesarian section is one of the skilled delivery attendance interventions that have proven to be a life saver. There are standard indications for its use in delivery. The practice of cesarean section in public and private hospitals has not been studied in Eritrea.

Objective: The purpose of this retrospective descriptive study was to examine the practice of caesarian section in public and private hospital in Eritrea.

Methods: The study used caesarian section data of 2007 from Orotta (public) and Sembel (private) maternity hospitals. The data was collected from the delivery records of both hospitals and was analyzed according to the time of the operation, indications, outcomes, and method of anesthesia used during the caesarian sections. Results: The rate of caesarian section delivery in this study was $10.4 \%$ [95\% Cl 9.3-11.5] in the public and $31.3 \%$ [95\% Cl of $26.2-36.4 \%]$ in the private hospital ( $p<0.001)$. In the public hospital $75.3 \%$ of the operations were emergency caesarian sections as compared to $47.6 \%$ in the private hospital $(p<0.001)$.

Conclusion: The indications for the operations in public and private hospitals were compliant with international benchmarks. The different rates could be attributable to that private hospital was serving more of those who required elective operations.

\section{Introduction}

Since becoming independent in 1991, Eritrea has faced many health challenges especially high maternal mortality. The maternal mortality rate witnessed a very welcome steady decline from $998 / 100000^{1}$ at the time of independence to near 450/100000 in $2005^{2}$.One of the success tools in decreasing maternal mortality could be delivering more and more women by caesarian section.

Caesarian section is one of the life saving medical interventions attributed to the decrease of the maternal mortality and morbidity rates. It is one of the best indicators for the quality of maternal health services offered in a country. The safety of the operation has improved with time, largely due to improved surgical and anesthetic techniques as well as the availability of blood transfusion services ${ }^{3}$.

The rise in the rate of cesarean section is seen worldwide. Once limited to western countries, particularly the United States and United Kingdom, high rates of cesarean deliveries are now an international phenomenon3. The reasons for the rise in the rate of caesarian section delivery include in part an increase in facility-based delivery and access to healthcare, convenience of delivery time as well as malpractice related financial gain ${ }^{4}$.

Reports show that population-based cesarean section rates exceeding the World Health Organization upper threshold of 15 percent are more common in private fee-for-service hospitals than in public hos pitals ${ }^{5}$. The phenomenon is seen in both developed and developing world with reports coming from the
Latin American countries 6,7,8, Asia9,10,11, Africa ${ }^{12}$ and Australia ${ }^{13}$.

In Eritrea, little or no research exists on levels and trends of cesarean section delivery and their stratification by place of delivery. The purpose of this study was to determine the prevailing rates of cesarean section in public and private hospitals in Eritrea and to explore the compliance with international benchmarks of the practice.

\section{Materials and Methods}

Study design: The study design was of a retrospective descriptive type that compared parturients by caesarian section in a public and a private hospital in Eritrea in 2007.

The study sites chosen were Orotta and Sembel Hospital delivery centers, both of which are located in Asmara, the capital city of Eritrea. Orotta Hospital was chosen to represent a public hospital because it is the national referral maternity hospital where more than $60 \%$ of the total cesarean sections are done in the country ${ }^{14}$. Sembel Hospital was chosen to represent private hospitals, as it was the only private hospital in Eritrea where caesarian section was done as a fee-forservice practice. Furthermore confounding factors like the quality of doctors and midwives was minimized because most of the health workers work in both places.

Sample size: From sample size determination formula using EPI table for comparisons of proportion between two groups, at a power of $95 \%$ and a Confidence level of $95 \%$, a minimum sample size of 
216 cases from Orotta and 72 from Sembel hospital was calculated respectively. A systematic sample of alternate months of the year 2007(the latest completed year record) was collected from the delivery records of both hospitals.

The total sample size of 390 collected [287 from Orotta and 103 from Sembel] was slightly more than the minimum sample size required.

Data analysis: A data entry file was created and research assistants (medical and nursing students and theatre nurses, with know-how on computer application) collected the data and entered it on an SPSS program file. The data was analyzed using the SPSS software version 11.

\section{Results}

The total number of deliveries in Orotta (public) and Sembel (private) Hospitals during the year 2007 was 8293 and 661, respectively. Out of the total, 931 cases in the public and 224 cases in the private hospital were delivered by caesarian section making the caesarian section delivery rate of each hospital at $11.2 \%$ [95\% $\mathrm{Cl} 10.5-11.9 \%]$ and $33.8 \%$ [95\% Cl of $30.1-37.5 \%]$, respectively $(p<0.001)$.

In the months sampled for the study, the rate of caesarian section delivery was $10.4 \%[95 \% \mathrm{Cl}$ 9.3$11.5]$ in the public and $31.3 \%$ [95\% Cl of $26.2-36.4 \%]$ in the private hospital $(p<0.001)$. The two hospitals were compared according to many variables. When total deliveries in both hospitals are considered, the private hospital contributed to $7.3 \%(661 / 8954)$ of the total deliveries but $19.3 \%$ (224/1155) of the caesarian deliveries. The relative risk of undergoing a caesarian section in the private hospital was $7.3(95 \% \mathrm{Cl}$ of $6.3-$ 8.3) times that in a public hospital. When the time of the procedure is considered, $75.3 \%$ of the operations in the public hospital were emergency caesarian sections as compared to $47.6 \%$ in the private $(p<0.001)$ (Table 1).

Repeat caesarian sections and cephalo-pelvic disproportion were the number one and number two most common indications in both hospitals with no statistically significant difference between the two hospitals. Prolonged labor, breech presentation and ante partum hemorrhage were more in the public hospital ( $p<0.001)$. Bad obstetric history and multi fetal pregnancies were more common in the private hospital ( $p<0.001)$, while fetal distress and preeclampsia were similar for both hospitals. Previous caesarian section delivery accounted for $49.3 \%$ of the indications for elective operations in the public hospital, as compared to $25.9 \%$ in the private hospital. For emergency caesarian sections, the figures were $11.6 \%$ versus $14.3 \%$.

Spinal anesthesia was used more in the private than in the public hospital: $94.2 \%$ versus $62 \%(p<0.001)$. This difference remained to be true even when the time of the operation was considered. When Apgar score was compared, $99 \%$ of the neonates born in the private hospital were rated 7 and above while $89 \%$ in the public hospital rated the same $(p<0.021)$. When the cases were stratified according to time of the operation, the difference was insignificant for the elective operations and the difference was due to 14 stillbirths among the emergency operations done in the public hospital. There was no statistically significant difference between blood lost per operation in the private and the public hospital. The mean blood lost was $433 \mathrm{ml}$ while the maximum blood lost was $2000 \mathrm{ml}$ which happened in a woman with a ruptured uterus in the public hospital.

\begin{tabular}{|c|c|c|c|c|}
\hline \multirow{2}{*}{$\begin{array}{l}\text { Indication for the } \\
\text { caesarian section }\end{array}$} & & \multicolumn{2}{|l|}{ Hospital } & \multirow[t]{2}{*}{ Total } \\
\hline & & $\begin{array}{l}\text { Orotta } \\
\text { (public) }\end{array}$ & $\begin{array}{l}\text { Sembel } \\
\text { (private) }\end{array}$ & \\
\hline $\begin{array}{l}\text { Previous caesarian } \\
\text { section }\end{array}$ & $\begin{array}{l}\text { Count Percent } \\
\text { within hospital }\end{array}$ & $\begin{array}{c}60 \\
20.9 \%\end{array}$ & $\begin{array}{c}21 \\
20.4 \%\end{array}$ & $\begin{array}{c}81 \\
20.8 \%\end{array}$ \\
\hline $\begin{array}{l}\text { Cephalo-pelvic } \\
\text { disproportion }\end{array}$ & $\begin{array}{l}\text { Count Percent } \\
\text { within hospital }\end{array}$ & $\begin{array}{c}50 \\
17.4 \% \\
\end{array}$ & $\begin{array}{c}20 \\
19.4 \%\end{array}$ & $\begin{array}{c}70 \\
17.9 \%\end{array}$ \\
\hline Fetal distress & $\begin{array}{l}\text { Count Percent } \\
\text { within hospital }\end{array}$ & $\begin{array}{c}41 \\
14.3 \% \\
\end{array}$ & $\begin{array}{c}9 \\
8.7 \% \\
\end{array}$ & $\begin{array}{c}50 \\
12.8 \%\end{array}$ \\
\hline $\begin{array}{l}\text { Prolonged } \\
\text { labor }\end{array}$ & $\begin{array}{l}\text { Count Percent } \\
\text { within hospital }\end{array}$ & $\begin{array}{c}35 \\
12.2 \% \\
\end{array}$ & $\begin{array}{c}7 \\
6.8 \% \\
\end{array}$ & $\begin{array}{c}42 \\
10.8 \% \\
\end{array}$ \\
\hline $\begin{array}{l}\text { Breech } \\
\text { presentation }\end{array}$ & $\begin{array}{l}\text { Count Percent } \\
\text { within hospital }\end{array}$ & $\begin{array}{c}34 \\
11.8 \% \\
\end{array}$ & $\begin{array}{c}6 \\
5.8 \%\end{array}$ & $\begin{array}{c}40 \\
10.3 \% \\
\end{array}$ \\
\hline $\begin{array}{l}\text { Bad obstetric } \\
\text { history }\end{array}$ & $\begin{array}{l}\text { Count Percent } \\
\text { within hospital }\end{array}$ & $\begin{array}{c}13 \\
4.5 \%\end{array}$ & $\begin{array}{c}14 \\
13.6 \%\end{array}$ & $\begin{array}{c}27 \\
6.9 \%\end{array}$ \\
\hline $\begin{array}{l}\text { Failed induction of } \\
\text { labor }\end{array}$ & $\begin{array}{l}\text { Count Percent } \\
\text { within hospital }\end{array}$ & $\begin{array}{c}11 \\
3.8 \% \\
\end{array}$ & $\begin{array}{c}11 \\
10.7 \%\end{array}$ & $\begin{array}{c}22 \\
5.6 \%\end{array}$ \\
\hline $\begin{array}{l}\text { Ante-partum } \\
\text { hemorrhage }\end{array}$ & $\begin{array}{l}\text { Count Percent } \\
\text { within hospital }\end{array}$ & $\begin{array}{c}13 \\
4.5 \% \\
\end{array}$ & $\begin{array}{c}1 \\
1 \% \\
\end{array}$ & $\begin{array}{l}14 \\
6 \% \\
\end{array}$ \\
\hline $\begin{array}{l}\text { Multi-fetal } \\
\text { pregnancy }\end{array}$ & $\begin{array}{l}\text { Count Percent } \\
\text { within hospital }\end{array}$ & $\begin{array}{c}4 \\
1.4 \%\end{array}$ & $\begin{array}{c}5 \\
4.9 \% \\
\end{array}$ & $\begin{array}{c}9 \\
2.3 \% \\
\end{array}$ \\
\hline $\begin{array}{l}\text { Pre-Eclampsia and } \\
\text { Eclampsia }\end{array}$ & $\begin{array}{l}\text { Count Percent } \\
\text { within hospital }\end{array}$ & $\begin{array}{c}4 \\
1.4 \% \\
\end{array}$ & $\begin{array}{c}1 \\
1 \% \\
\end{array}$ & $\begin{array}{c}5 \\
1.3 \% \\
\end{array}$ \\
\hline Ruptured uterus & $\begin{array}{l}\text { Count Percent } \\
\text { within hospital }\end{array}$ & $\begin{array}{c}2 \\
7 \%\end{array}$ & $\begin{array}{c}0 \\
0 \%\end{array}$ & $\begin{array}{c}2 \\
.5 \%\end{array}$ \\
\hline Miscellaneous & $\begin{array}{l}\text { Count Percent } \\
\text { within hospital }\end{array}$ & $\begin{array}{l}20 \\
7 \%\end{array}$ & $\begin{array}{c}8 \\
7.8 \% \\
\end{array}$ & $\begin{array}{c}28 \\
7.2 \%\end{array}$ \\
\hline Total & $\begin{array}{l}\text { Count Percent } \\
\text { within hospital }\end{array}$ & $\begin{array}{c}287 \\
100 \%\end{array}$ & $\begin{array}{c}103 \\
100 \%\end{array}$ & $\begin{array}{c}390 \\
100 \%\end{array}$ \\
\hline
\end{tabular}

\section{Discussion}

Eritrea, as a relatively new African nation, is not expected to have a high rate of caesarian section. But this study has shown that the rate is already high, at least in the capital city of Eritrea. Furthermore, a marked $(21.9 \%)$ and statistically significant $(p<.001)$ difference was observed in the rate of caesarian section between a public (10.4\%) and private hospital (31.3\%).

Although the private hospital contributed for $19.3 \%$ (224/1155) of the caesarian deliveries between both hospitals, the impact of the private practice on the rise or caesarian section rate may not be prominent as it shares only $7.3 \%$ of the total deliveries.

The national rate of caesarian section is below $2 \%{ }^{14}$. The rate of caesarian section in the public hospital in 1998 was $10 \%$ and has barely changed during $2007(11.2 \%)^{14}$. No data was available for the previous 
years. The private hospital became operational in 2003 and thus the trend of the rise within a longer period could not be compared.

The finding in this study, that the rate of caesarian section in a private hospital of Eritrea is already high is in agreement with studies done in other developing countries $^{4,6-13}$. The forces behind increased caesarian section rate identified or presumed in the above referenced studies, like the malpractice concerns, time convenience of delivery as well as financial (profitability) reasons seem to be true in this study as there is disproportionate rate between the private and public hospitals.

The strong arguments in some of the studies ${ }^{6-10}$ stating, "the increased caesarian section rate in the private practice was medically unnecessary" was primarily based on the increased rate. Few of them have strictly analyzed the reasons behind the operation or evaluated them with respect to their outcomes in terms of neonatal and maternal morbidity and mortality.

This study analyzed the indications for caesarian sections and has found that the indications are very similar and proportionate in both the public and private hospitals.

The ranking of the indication as well as their prevalence was also similar to international studies done to identify the commonest indications for caesarian sections ${ }^{15}$. The proportion of caesarian sections done for a failed trial of vaginal birth after caesarian section (VBAC), a good obstetric practice, is more in the private (14.3\%) than in the public (11.6) hospital. All of the above arguments suggest that the caesarian sections done in both hospitals were equally medically sound and none was unnecessary.

During this study period no maternal death attributable to caesarian section was reported in both hospitals. The lower Apgar score and the 14 stillbirths in the public hospital could cast doubt as to the quality of the care in the public hospital. Yet as the public hospital accepts all referral cases it is clear that patients may be received in late stages, when it becomes difficult to salvage the babies.

It can be concluded from this study that the difference between the public and private hospital is more in the time of the operation, as over half of the operations in the private hospital were done on elective bases. It may be reasonable to say that the private hospital accepts more patients who require an elective operation and can afford to pay for it; otherwise the operations were not unnecessary. The results reported in this study may reflect the need for further comprehensive studies to better understand the precise forces sustaining these trends of increased caesarian section delivery rate in their broader context, and to develop appropriate policies and guidelines for performing and monitoring cesarean deliveries in Eritrea. Yet the study has set a platform where to start.

\section{Limitations of the study}

A nationwide survey could have been more conclusive since this study was done only in the capital city, Asmara, A future nationwide prospective study would address some of these limitations

\section{Acknowledgements}

My thanks are extended to the Ministry of Health, Eritrea and to hospitals for the use of the data as well as to the students who retrieved data from the delivery registry records and entered them into an SPSS program file.

\section{References}

1. Eritrea Demographic and Health survey 1995. National statistics office. Department of macro policy and international cooperation. Office of the president. Eritrea \& DHS. Macro international. March 1997.

2. World Health Organization 2007. Maternal Mortality in 2005. Estimates developed by WHO, UNICEF, UNFPA, and The World Bank. Annex 3 p 24

3. Editorial. Caesarean section on the rise. Lancet. 2000; 356:1697.

4. Guo Sufang; Sabu S Padmadas; Zhao Fengmin; James J Brown; R William Stones. Delivery settings and caesarean section rates in china. Bulletin of world health Organ vol.85 no.10 Genebra Oct. 2007

5. UNICEF, World Health Organization, United Nations Population Fund. Guidelines for Monitoring the Availability and Use of Obstetric Services New York: United Nations Children's Fund, 1997:1-103.

6. Belizan JM, Althabe F, Barros FC, Alexander S. Rates and implications of caesarean section in Latin America: Ecological study. BMJ. 1999; 319:1397-1400.

7. Juarez Ocana SJ, Fajardo Gutierrez A, Perez Palacios G, Guerrero Morales RG, Gomez Delgado A. The trend in pregnancies terminated by a caesarian operation in Mexico during 1991-1995. Unidad de Investigacion Medica en Epidemiologia Clinicia, Hospital de Pediatria, CMN Siglo XXI, IMSS, MEX. D.F (In Spanish)

8. Leung GT, Lam H, Thach TQ, et al. Rates of cesarean births in Hong Kong: 1987-1999. Birth. 2001; 28:166-172.

9. Villar J and the WHO 2005 global survey on maternal and perinatal health research group. Caesarian delivery rates and pregnancy outcomes: the 2005 WHO global survey on maternal and perinatal health in Latin America. Lancet, 2006 Jun 3; 367(9525): 1819-29

10. Hanvoravongchai $P$, Leitiendumrong J, Teerawattanan $Y$, Tangcharoensathien V. Implications of Private practice in public hospitals on the caesarian rate in Thailand. An international journal for HRH development ISSN 80598037, Jan-Apr 2000 Vol 4 No 1

11. Bhasin Sk, Rajoura OP, Sharma AK, Metha M, Gupta N, Kumar S, Joshi ID. A high prevalence of caesarean section rate in east Delhi. Indian J Community Med 2007; 32:222224

12. Khawaja $M$, Jurdi $R$, and Kabakian $T$. Rising trends in Caesarian Section Rates in Egypt. Birth, 2004 March; 31(1): 12-16

13. Trisha C Johnston and Michael D Coory. Increase in caesarian section rates among low-risk women in Queensland, 19902004. MJA 2008; 185(7): 404-405

14. Health System Information System, MOH Eritrea. Decision Support System database 2007

15. Natzan FC, Cnaltingus S, Bergsjo P, Cole S, Tueffel S, Ingenes L, Dalveit AK. Caesarian delivery in the 1980s; International comparison for indication. Am J Obstet Gynecol 170:495, 1994 